\title{
Analysis of EFL Teaching Methods for Taiwan University Students
}

\author{
Ching-ning Chien \\ Department of Applied Linguistics and Language Studies, Chung Yuan Christian University, Zhongli, Taiwan
}

\begin{abstract}
This study looks into three outstanding EFL teachers' classrooms in a Taiwan university setting using teachers' syllabi, questionnaire surveys, interviews with students and teachers, and evidence of students' improvements in English proficiency. The teaching methods have proven to be effective in achieving results and are appreciated by the teachers' students. Their teaching methods adopted in the classrooms were analyzed and identified. A paired t-test was used to examine the students' improvement between a pre-MEPT proficiency test and a post-MEPT proficiency test. Questionnaires and interviews were used to gain insight into the students' perceptions of learning experiences. The teachers were also observed and interviewed about what methods and how they utilized to help students learn. The study found that (1) classroom teaching is not attributed to a single superior method; (2) cooperative learning techniques of Communicative Language Teaching and Cooperative Learning methods combined with traditional Grammar-Translation teaching instruction worked effectively for university students; learning tends to take place when students are willing to actively participate in learning activities which might be something new or challenging to them; (3) the paired t-tests proved that the students of all three teachers made statistically significant improvement in overall performance over students in the Freshman English classes.
\end{abstract}

Index Terms-cooperative learning, EFL context, learner-centered, EFL teaching methods, students' perspective

\section{INTRODUCTION}

Taiwanese students' English competency emerges with two extremes - either very good or very poor. This phenomenon reflects across primary school, high school and college students (Lo, 2005; San, 2005). According to Chien and her colleagues' study of 4,250 freshman non-English majors (2011), university students realized the importance of English for their current academic pursuits and future professional careers. They also had a desire to be able to communicate with foreigners in English. Under these conditions, students should be motivated to make an effort to improve English after entering the university. However, quite a portion of university students feel their English ability keeps declining year after year since the time they attend university, compared with the time in which they studied English more hours in high school. Previous studies have also shown that students' expectations of English programs in university have not been satisfied (as cited in Chien, 2014). After having put in so much effort and time working with students, many teachers are also disappointed by the reactions and comments on the Student Evaluation of Teaching reports (SET). How can the EFL teachers help students learn? There is no doubt that teachers' teaching methods and practices all contribute to a successful teaching. This study aims to compare the teaching methods and practices of the three favorable model teachers' teaching in the EFL classrooms for a non-English majors' program in a Taiwanese university.

\section{Literature REVIEW}

Chien (2014) has reviewed the studies regarding foreign language learning and teaching to help foreign language learners. The mostly frequently adopted teaching methods in the EFL contexts have included the Grammar-Translation method (GT), Communicative Language Teaching (CLT) and Cooperative Learning (CL). The GT method originated in Germany in the 1780s (Howatt \& Widdowson, 2004). By the early 19th century, however, the GT method suffered serious opposition, both from within Germany and from abroad (Howatt \& Widdowson, 2004). Much of this opposition came from the fact that the method was developed by scholars for scholars, requiring a high-degree of knowledge of the first language grammar. However, the GT method has been resurrected in recent years - albeit in a modified form-by combining it with CLT techniques (Sapargul \& Sartor, 2010). Methodical review of second/foreign language teaching reveals that a significant shift in the field towards communicative teaching has taken place on the basis of many theoretical propositions and insights from anthropology, sociolinguistics, psycholinguistics, and communications concerning the notion of communicative competence. The roots of the transition to communicative teaching can actually be traced back to the 1960s (Richards \& Rogers, 2001) and is partially attributed to Noam Chomsky's Syntactic Structures which claimed that the theories adopted by linguists at the time failed to take into account the creativity and uniqueness of language (Chomsky, 1957). Since then, CLT has been widely discussed and taught in language classrooms around the world, with no small thanks to the work of D.A. Wilkins. Wilkins' (1976) work on CLT, found in 
Notional Syllabi, an expansion of his earlier work (1972), contributed a great deal to the development of the teaching method that was still fairly new in his time. In the latter half of the 1970s, CLT continued to expand in scope (Richards \& Rogers, 2001). Yet while the scope of CLT was increasing, CLT's primary goal remained focused on teaching communicative competence in areas including grammatical competence, psycholinguistic or strategic competence, socio-cultural competence, and discourse competence (Savignon, 1983).

Today, CLT attends to the communicative needs of learners in the sense that instrumental and pragmatic aspects of language use are cultivated so that the motivations of the learners are more often better sustained than they are in the traditional GT method (Dornyei, 1997). Moreover, the CLT impact has encouraged language teachers to pay more attention to learner-centeredness in language teaching and learning (Brown, 2007; McComs \& Whisler, 1997). The learner-centered curriculum was described as a collaborative effort between teachers and learners (Nunan, 1988). In the learner-centered CLT approach, learners are allowed to express their opinions about language content (Richards, 2006). Learners collaborate with the English teacher to explore topics and are actively involved in the learning process. Because the learner-centered approach views learners as individuals who have rights in the process of deciding the course goal, it is believed their intrinsic motivation can thus be triggered and increased when learners' experiences, talents, needs, and learning styles are appreciated (Dornyei, 1997).

Cooperative Learning, which, as Richards and Rogers (2001) explained, shares many of the characteristics of CLT, promotes learning through communication in pairs or small groups and has been confirmed relatively recently as an effective method of learning (Millis \& Rhem, 2010). In the 1990s, CL was one of the most thoroughly researched areas in educational psychology (Johnson, Johnson \& Smith, 1995), and was regarded by some as a tool which is adaptable to any teaching/learning situation (Brody \& Davidson, 1998). CL is still regarded as a highly effective classroom intervention, superior to most traditional forms of instruction and it is applicable with some confidence at every level (Millis \& Rhem, 2010). The cooperative classroom is characterized by positive interdependence of students, as Johnson et al. noted, when one perceives that one is linked with others in a way so that one cannot succeed unless one must coordinate one's and others' efforts to complete a task. It is a type of 'sink or swim' together mentality. This is different from an individualistic classroom where students work independently and the chance of achieving a task is not enhanced by the presence of others. It appears that the CL process generates a specific motivational system that energizes learning (Millis \& Rhem, 2010). CL is theoretically one of the most efficient instructional methods from a motivational point of view. It can be seen that there are striking similarities between cooperative group skills emphasized by CL and the second/foreign language functions emphasized by CLT; this is why CL is also able to act as a foundation in Communicative Language curriculum design (Dornyei, 1997).

After reviewing the teaching methods above-mentioned, they can be summarized as the GT method, a traditional teaching method by which language teachers play an important role in the class, explaining vocabulary, grammatical rules and articles in the students' first language; the CLT method, a learner-centered approach in which language teachers help students take up more responsibility on their own to strengthen their communicative competency by using task-based activities, and the CL method, a team work approach in which language teachers encourage their students to seek cooperation with other learners for the completion of a given task or a project together, such as making an advertisement, film-making, or playing games in groups. This study aims to compare and contrast the three model teachers' teaching methods, and to identify the model teachers' common qualities observed from students' perspectives and finally to examine their students' learning outcomes from the course.

\section{Methodology}

The present study carefully investigated the views of the teaching methods of the 'most favorable' model teachers and the views of their students as well. The procedures included three model teacher selection, participating students selection and analysis of the English proficiency improvement of participating students. Research tools included student evaluation of teaching (SET), the questionnaire survey, students interviews, teacher interviews, and Michigan English Placement Test (MEPT). First of all, the three model participating teachers were identified from 50 60 teachers in the university. Secondly, the representative, sampled students were randomly selected from the 7 classes the model teachers were teaching. In order to achieve the study goals, information related to the teachers' teaching methods/practices was obtained through students' interviews by audiotape recordings as well as teacher interviews by filming videotapes. Furthermore, the classroom observations were arranged, and analytic memos and contact summaries for each teacher were written. All the tapes were transcribed and then coded. In addition, to examine the effectiveness of each teacher's teaching methods, the MEPT pre-test was administered at the beginning of the second semester and the same test (post-test) was given at the end of the second semester. A paired t-test was used to assess how much progress these students had achieved in the post-test MEPT. The details about the procedures are the same as described in the previous study (Chien, 2014).

\section{A. Student Evaluation of Teaching (SET)}

The SET is designed in the form of a Likert scale (1 5), plus open-ended questions designed for students to write comments.

\section{B. The Questionnaire Survey}


This questionnaire was sent to the 196 students at the beginning of the second semester. It consisted of 6 questions concerning the respondents' personal assessment of the importance of six language education elements. First, the teachers are using only English (the target language) in teaching (Q1), vocabulary teaching (Q2), grammar teaching (Q3), essay structure teaching (Q4), essay explanation (Q5), and classroom learning activities (Q6). In order to achieve the teaching objectives, teachers who use only English (Q1) tend to adopt the CLT method; those who favor classroom learning activities (Q6) are more likely to use the CLT and CL methods; while those who attend more to students' vocabulary and grammar growth might choose the GT or CLT method to teach vocabulary (Q2), grammar (Q3) and essay structure (Q4). The survey was conducted in the L1 in order to alleviate any confounding L2 comprehension effects.

\section{Student Interviews}

Six to seven students from each teacher (total of 19 students) participated in the audio-taped one-on-one interview for 30-35 minutes. The interview questions were: What impresses you most in the course of 'Freshman English'? What does the teacher do that helps you learn? How do these methods/techniques help you learn? What techniques are the teachers actually guiding you to practices from which you are benefiting by enhancing your language skills? These questions were to prompt the students to recall what and how they had learned in the class. After all the recordings had been transcribed, the transcriptions were independently gone through by the researcher and another experienced teacher, and all the ideas which appeared meaningful or valuable in the recalls were coded. Scoring the transcription involved awarding one point to any positive feedback with its meaning, which directly matched with the category of teaching methods and practices listed in the Tables.

\section{Teacher Interviews}

Each teacher was interviewed by the end of the second semester and all the interviews were transcribed. The interview questions were: How do you help your students learn English? How do these methods/techniques help them learn? Why do these methods/techniques help them learn? The questions helped reveal not only the weight of using different teaching methods, but also the pedagogical theories that the teachers used. The interviews were filmed in a very relaxing atmosphere.

\section{DATa Analysis AND Result Discussion}

This section presents the analytic results of the teachers' teaching methods from the datasets collected from the questionnaire surveys, student interviews, teacher interviews, and classroom observations plus the teacher's course syllabus. The results include similarities and differences in teaching views among the three model teachers and among different proficiency levels of students (section 4.1). Also, it determines what common phenomena are observed in the classrooms and from the syllabi (section 4.2), and how the transcription of student interviews is scored (section 4.2). In addition, it displays the results of the students' performance in the MEPT pre-test and in the MEPT post-test (section 4.3).

\section{A. Similarities and Differences in Teaching Views among Three Teachers and Their Students}

Figures 1 and 2 summarize and compare the importance levels of English teaching elements from the viewpoints of teachers and their students, respectively, using the questionnaire survey. Figure 1 indicates that the importance levels of all six elements are considered higher than 2, i.e., "somewhat important" at least, by three model teachers. All three teachers agree on the same importance level of vocabulary teaching (Q2) for students at different levels of English proficiency. Teacher Chang teaches low level students with an emphasis on grammar teaching (Q3) and structure teaching (Q4) as blue bars show. Teacher Her teaches intermediate level students with more emphasis on classroom learning activities (Q6) and less emphasis on grammar teaching (Q3) and essay explanation (Q5) as red bars show. Teacher Chen gives equal weight to all the elements except in the area of using English (Q1) only for her students with English proficiency at the high-intermediate level as green bars show. This bar figure reveals the different emphases on the teaching elements, which are probably caused by the English proficiency levels of students. The different emphases will reflect upon the syllabi, teaching methods, teaching practices and teaching activities used by the three teachers. A further discussion will be addressed in the following sections. 


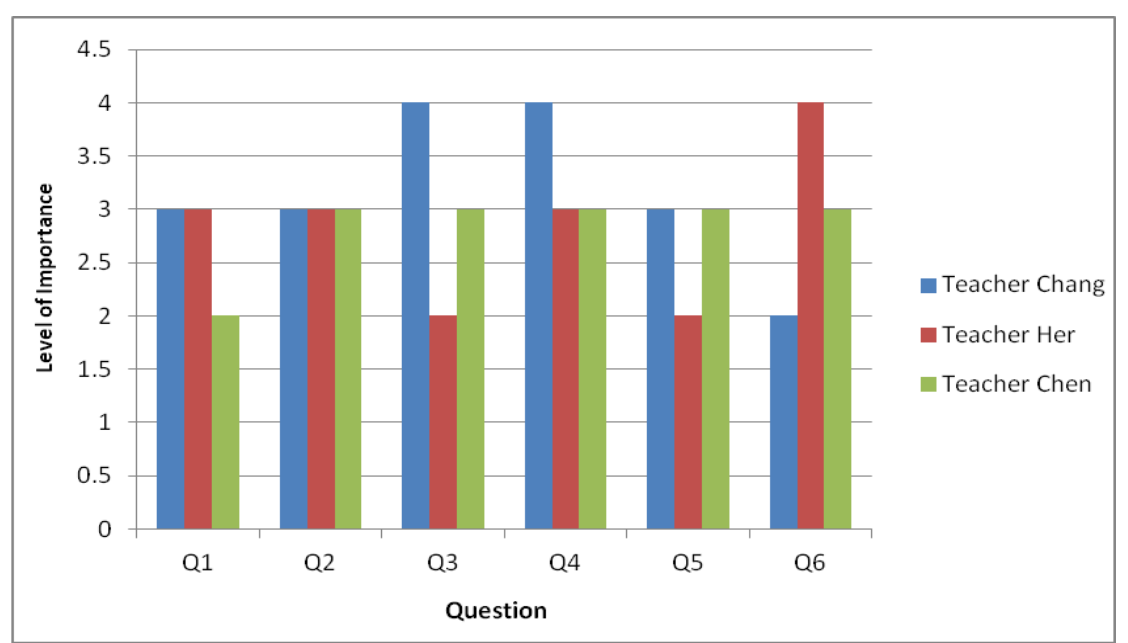

Figure 1. Comparisons of the Levels of Importance for Various Elements in English Teaching Among Three Teachers, Teacher Chen, Teacher Her and Teacher Chang

Q1. Using English only in Teaching $1=$ Not Important

$$
\begin{array}{cc}
\text { Q2. Vocabulary teaching 2= Somewhat Important } \\
\text { Q3. Grammar teaching } & \text { 3= Important } \\
\text { Q4. Article structure teaching } & \text { 4= Very Important } \\
\text { Q5. Essay explanation } \quad \text { Q6. Classroom learning activities }
\end{array}
$$

Compared with Figure 1, Figure 2 shows that the students do not agree with their teachers on the importance levels of different teaching elements. Moreover, the students at different English levels weight the importance levels of six teaching elements (Q1 to Q6) differently, except that all students agree to a similar importance level of article structure teaching (Q4) ranging from $54 \%$ to $62 \%$. Students at the low English proficiency level weight more on vocabulary teaching (Q2) and using English only in teaching (Q1), students at the intermediate level weight more on essay explanation (Q5) and the least on vocabulary teaching (Q2), but students at the high-intermediate level agree with the teacher on the weight of the importance levels for all teaching elements, and more weight on grammar teaching (Q3), essay explanation (Q5), and using English only in teaching (Q6). The observations indicate that more than $74 \%$ to $84 \%$ of students in the high-intermediate English level desire more training on grammar teaching (Q3) as well as essay explanation (Q5) and listening comprehension (Q1). Approximately $83 \%$ of students in the intermediate English level desire more training on essay explanation (Q5) but less than $10 \%$ of them desire the training on vocabulary (less than $10 \%$ ). For students in the beginning English level, more than $85 \%$ of them view vocabulary teaching (Q2) as important; while less than $40 \%$ veiw classroom learning activities (Q6) as important. Figure 2 also shows that classroom learning activities (Q6) receives a relatively low rating by students at all three English levels. The percentages reveal students' viewpoints of teaching elements of English learning. They may reflect what teaching methods are employed by teachers and how they are accepted by students. The teaching methods derived from the teaching elements are the focus of this study.

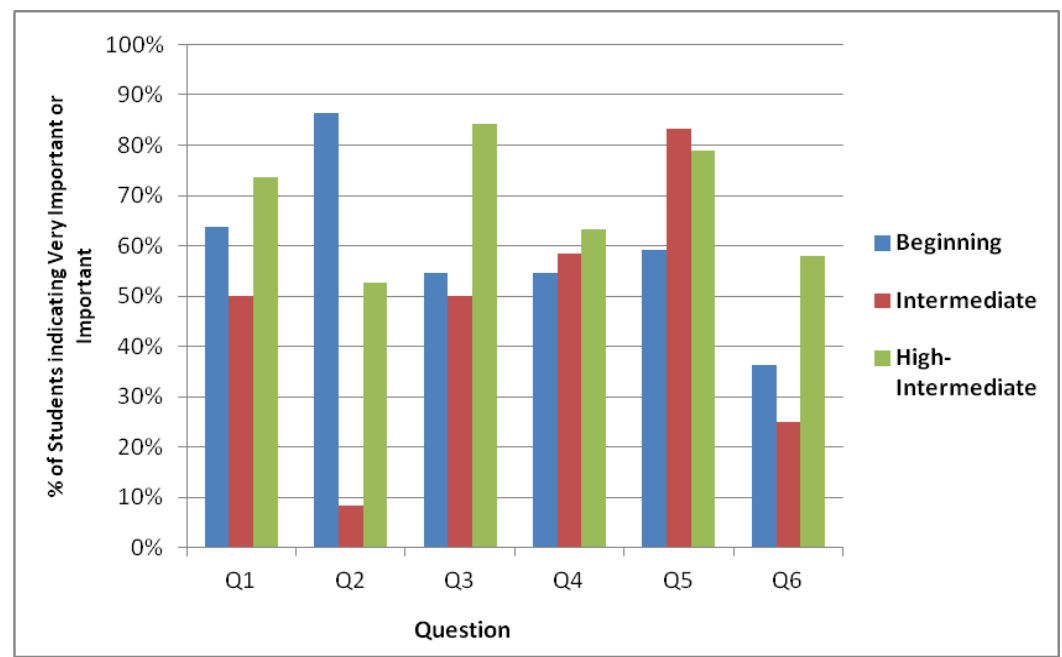

Figure 2. Comparisons of Viewpoints on Importance of Various Items in English Teaching Given by Classes of Different English Levels

\section{B. Results on Identifying Teaching Methods from Course Syllabi, Student Interviews, Teacher Interviews and Classroom Observation}


This paper analyzes the teaching methods according to the associated pedagogy from the syllabi, classroom observation, teacher interviews as well as students' recalls on the learning activities and learning practices coded from the interview transcriptions.

Table 1 summarizes the pedagogies correlating with the syllabus contents from the syllabi and categorizes teaching methods from classroom observation of the three model teachers, and teacher interviews. Teacher Chang's syllabus is the simplest among three teachers with an emphasis on the basic skills using all existing methods of GT, CLT, and CL, designed for students at the low English proficiency level. Teacher Her's syllabus targets reading strategies specifically plus attention to diction, vocabulary, and tone by varieties of activities and demands students to pay additional effort, in, before and after classes, mainly using CLT and CL methods, designed for students at the intermediate English proficiency level. Teacher Chen's syllabus is directed toward the enhancement of vocabulary, reading and speaking. She flexibly adopts a combined CL-GT method as well as GT, CLT, CL methods for teaching activities, designed for students at the intermediate-high English proficiency level. This table indicates obviously that extra effort has been made to think out more varieties of teaching methods for students at a higher English proficiency level.

Furthermore, from the teachers' interview, the researcher found that Teacher Chang, Teacher Her, and Teacher Chen spend $70 \%, 60 \%$, and $40 \%$ of the class time in lecturing, that is, students use up about $30 \% .40 \%$, and $60 \%$ of the class time, respectively. It indicates that there has been an increase of time for student participation from the classes of the beginning level to the classes of the intermediate level to the classes of the intermediate-high level; namely. more time is spent on freely using CLT and CL methods for higher English levels of students.

TABLE 1.

TEACHING METHODS OBSERVED AND CATEGORIZED FROM SYLLABI/ TEACHER INTERVIEWS/CLASSROOM OBSERVATIONS

\begin{tabular}{|c|c|c|}
\hline Teacher & Syllabus content & Associated pedagogy and teaching methods \\
\hline Chang & $\begin{array}{l}\text { To develop four basic skills. } \\
\text { Students are exposed to } \\
\text { authentic, natural English to } \\
\text { build understanding and } \\
\text { expression. }\end{array}$ & $\begin{array}{l}\text { GT method: teaching grammar, vocabulary, sentence structure; verb tense, subjunctive } \\
\text { mood clause in Chinese } \\
\text { CLT method: designing learner-centered activities to keep students working by } \\
\text { themselves or with others } \\
\text { CL method: arranging group discussion and group presentation }\end{array}$ \\
\hline Her & $\begin{array}{l}\text { To improve reading } \\
\text { comprehension and speed; } \\
\text { Students are taught to be critical } \\
\text { and appreciative readers. } \\
\text { Attention to diction, vocabulary, } \\
\text { tone and enhancing reading } \\
\text { comprehension, and the author's } \\
\text { purpose. }\end{array}$ & $\begin{array}{l}\text { CLT method: designing learner-centered activities to encourage students to work by } \\
\text { themselves or with others; teaching reading strategies; finding key words, main ideas, } \\
\text { ways to guess the meaning of unfamiliar words from the context, etc.; assigning } \\
\text { homework a week before, discussing, checking the homework answers in class; playing } \\
\text { the tape or films in class so students have a chance to read sentences out loud and to } \\
\text { listen to the natives; using English as much as possible in class; asking students to } \\
\text { discuss the group presentation content with the teacher via e-mail before they present } \\
\text { their group work in class } \\
\text { CL approach: arranging group presentation for students to practice talking in English }\end{array}$ \\
\hline Chen & $\begin{array}{l}\text { To focus on vocabulary and } \\
\text { phrase increase; } \\
\text { to practice reading strategies, } \\
\text { enhance reading comprehension } \\
\text { and improve } \\
\text { speaking ability. }\end{array}$ & $\begin{array}{l}\text { GT method: increasing vocabulary knowledge and phrase knowledge. } \\
\text { CL combined with GT method: using interactive activities, in which both students and } \\
\text { the teacher work together responsible for explaining the meaning of the articles. Chinese } \\
\text { is allowed during the discussion in class } \\
\text { CLT method: giving every student in each group a role to play for their responsibility; } \\
\text { i.e., the group leader in the classroom activity, who assigns the responsibility to each } \\
\text { member, keeps all students alert, or the time-keeper who watches the time for the } \\
\text { discussion; grouping students to participate in the discussion, two students from each } \\
\text { group are randomly selected to explain the articles (Chinese is allowed); giving } \\
\text { immediate comments right after group presentation in class and more detailed remarks } \\
\text { later in the written paper } \\
\text { CL method: using task-based or project-based language teaching, e.g., sharing } \\
\text { advertisements and analyzing advertising techniques after giving a written instruction } \\
\text { and a demo a week before. (Chinese is not allowed for group presentation); arranging } \\
\text { group presentation, providing students an opportunity to work together and to express } \\
\text { their feelings or opinions in English. }\end{array}$ \\
\hline
\end{tabular}

Table 2 displays the most memorable teaching activities and the associated teaching methods from analyzing the scored student interview transcription. Recognized teaching methods are identified thus; 1 s 3 represents the $3 \mathrm{rd}$ student (s3) in Teacher Chang (t1)'s class, t3s 3 represents the $3^{\text {rd }}$ student in Teacher Chen's class, and so on. In first column of the table, the teaching methods are associated with the teaching activities in second column. The $3^{\text {rd }}$ column tabulates the specific students who recalled the specific and impressive teaching activity listed in $2^{\text {nd }}$ column in $1^{\text {st }}$ teacher's (Teacher Chang's) class. Column 3 of Table 2 identifies that 1 student credits the practice of Chinese translation (GT method), 5 students credit the interactive activities (CLT method), 7 students credit the group discussion (CL method), 4 students credit the team work for vocabulary and reading enhancement (CL method), and 2 students favor the effort of playing games (CL method) in Teacher Chang's class of 7 students. It indicates that all the 7 students favor the group discussion, next the 5 students are for the interactive activities in Teacher Chang's class at the low English proficiency level. The $4^{\text {th }}$ column indicates that 3 students favor interactive activities, all 6 students favor group discussion, 5 students favor the team work of enhancing vocabulary and reading; and 4 students favor playing games in Teacher Her's class of 6 students at the intermediate English proficiency level. The $5^{\text {th }}$ column stands out for the appreciation of group discussion by all 6 students in Teacher Chen's class of 6 students at high-intermediate English proficiency level. 
The number in $6^{\text {th }}$ column indicates all 19 students credit the effort of group discussion; next, the team work of enhancing vocabulary and reading; then, the interactive activity. The summary implies that the CL method is more recognized by students then the CLT method, and the GT, the last, no matter what the English proficiency level of students is. This table also shows that more activities associated with the CL method were used by three model teachers.

TABLE 2.

RECOGNIZED TEACHING METHODS IDENTIFIED FROM STUDENT INTERVIEW TRANSCRIPTION SCORING

\begin{tabular}{|c|c|c|c|c|c|}
\hline Teaching Method & Teaching Activities & $\begin{array}{l}\text { Teacher Chang } \\
\text { (Teacher } 1: \mathrm{t} 1)\end{array}$ & $\begin{array}{l}\text { Teacher Her } \\
(\text { Teacher 2: } \mathrm{t} 2)\end{array}$ & $\begin{array}{l}\text { Teacher Chen } \\
\text { (Teacher 3: t3) }\end{array}$ & $\begin{array}{l}\text { Total } \\
\text { Count }\end{array}$ \\
\hline GT method & Translation into Chinese & $\begin{array}{l}1 \\
\mathrm{t} 1 \mathrm{~s} 3\end{array}$ & 0 & $\begin{array}{ll}1 \\
\mathrm{t} 3 \mathrm{~s} 3\end{array}$ & 2 \\
\hline CLT method: & Interactive activities & $\begin{array}{l}5 \\
\mathrm{t} 1 \mathrm{~s} 2, \mathrm{t} 1 \mathrm{~s} 3, \mathrm{t} 1 \mathrm{~s} 4, \mathrm{t} 1 \mathrm{~s} 6, \mathrm{t} 1 \mathrm{~s} 7\end{array}$ & $\begin{array}{l}3 \\
\mathrm{t} 2 \mathrm{~s} 2, \mathrm{t} 2 \mathrm{~s} 4, \mathrm{t} 2 \mathrm{~s} 5\end{array}$ & $\begin{array}{l}2 \\
\mathrm{t} 3 \mathrm{~s} 1, \mathrm{t} 3 \mathrm{~s} 5\end{array}$ & 10 \\
\hline CL method: & $\begin{array}{l}\text { Task-based approach: } \\
\text { Collaborative work } \\
\text { through group discussion }\end{array}$ & $\begin{array}{l}7 \\
\text { t1s1, t1s2,t1s3, t1s4, t1s5, } \\
\text { t1s6,t1s7 }\end{array}$ & $\begin{array}{l}6 \\
\mathrm{t} 2 \mathrm{~s} 1, \mathrm{t} 2 \mathrm{~s} 2, \mathrm{t} 2 \mathrm{~s} 3, \mathrm{t} 2 \mathrm{~s} 4, \\
\mathrm{t} 2 \mathrm{~s} 5, \mathrm{t} 2 \mathrm{~s} 6\end{array}$ & $\begin{array}{l}6 \\
t 3 s 1, t 3 s 2, t 3 s 3 \\
t 3 s 4, t 3 s 5, t 3 s 6 \\
\end{array}$ & 19 \\
\hline CL method: & $\begin{array}{l}\text { Activities by team work. } \\
\text { Students are challenged to } \\
\text { increase vocabulary or } \\
\text { advance reading } \\
\text { comprehension }\end{array}$ & $\begin{array}{l}4 \\
\mathrm{t} 1 \mathrm{~s} 1, \mathrm{t} 1 \mathrm{~s} 5, \mathrm{t} 1 \mathrm{~s} 6, \mathrm{t} 1 \mathrm{~s} 7\end{array}$ & $\begin{array}{l}5 \\
\mathrm{t} 2 \mathrm{~s} 1, \mathrm{t} 2 \mathrm{~s} 2, \mathrm{t} 2 \mathrm{~s} 3, \mathrm{t} 2 \mathrm{~s} 4, \\
\mathrm{t} 2 \mathrm{~s} 6\end{array}$ & $\begin{array}{l}2 \\
\mathrm{t} 3 \mathrm{~s} 4, \mathrm{t} 3 \mathrm{~s} 5\end{array}$ & 11 \\
\hline CL method: & $\begin{array}{l}\text { Playing games by } \\
\text { individuals or in groups }\end{array}$ & $\begin{array}{l}2 \\
\mathrm{t} 1 \mathrm{~s} 5, \mathrm{t} 1 \mathrm{~s} 6\end{array}$ & $\begin{array}{l}4 \\
\mathrm{t} 2 \mathrm{~s} 3, \mathrm{t} 2 \mathrm{~s} 4, \mathrm{t} 2 \mathrm{~s} 5, \mathrm{t} 2 \mathrm{~s} 6\end{array}$ & $\begin{array}{l}3 \\
\mathrm{t} 3 \mathrm{~s} 3, \mathrm{t} 3 \mathrm{~s} 4, \mathrm{t} 3 \mathrm{~s} 5\end{array}$ & 9 \\
\hline Total counts & & 19 & 18 & 14 & 51 \\
\hline
\end{tabular}

As for the teaching practices, the participating students were interviewed about whether their English skills had been practiced in class and whether their skills had been improved through the course. Table 3 reports the number of the times about certain specific skills were exercised by the students and they felt that they were making a breakthrough in using the skills. Thus, the counts in the table reveal the appreciation of major teaching practices. The record shows that 39 times for vocabulary, 20 times for reading comprehension, 19 times for listening comprehension, 17 times for grammatical knowledge and 20 times for cooperative learning, students felt they were being benefited from the practices. These results are in accordance with the previous findings related to the CLT or CL approach on EFL college learners (i.e., Johnson et al., 1995; Wei, 1996; Chen, 2001; Magno \& Sembrano, 2007; Wang, 2007; Khandelwal, 2009; Strong, Gargani, \& Hacifazlioglu, 2011).

In addition, the larger the numbers in each item, the more the students are satisfied with the learning in practice. For example, it is reported 39 times that they learned the strategies to enlarge their vocabulary. Out of the 19 interviewees, 12 reported that their listening ability was enhanced; 15 out of 19 indicated that their reading ability was advanced and 10 out of 19 claimed that they had better understanding of the grammar. It also shows that all the 19 participating students learned communication skills by getting involved more actively in group work. Comparatively, they spent more time just sitting and listening in high school English class, but they reported speaking more during class time in college. They enjoyed seeing the work of other groups when they were doing presentations. The English class turned some of their attention from paperwork to more communicative activities, which made the class time more enjoyable and absorbing. It is interestingly noted that major practices using the GT method, the CLT method, and the CL methods are equally effective and appreciated for all English proficiency levels of students, and help in vocabulary increase is the most cited practice. 
TABLE 3.

TEACHING PRACTICES IDENTIFIED FROM STUDENT INTERVIEW TRANSCRIPTION SCORING

\begin{tabular}{|c|c|c|c|c|c|}
\hline & Teaching Practices & $\begin{array}{l}\text { Teacher Chang } \\
(\text { Teacher } 1: \mathrm{t} 1)\end{array}$ & $\begin{array}{l}\text { Teacher Her } \\
\text { (Teacher 2: t2) }\end{array}$ & Teacher Chen (Teacher 3: $\mathrm{t} 3$ ) & $\begin{array}{l}\text { Total } \\
\text { Count }\end{array}$ \\
\hline $\begin{array}{l}\text { GT Method } \\
\text { or CLT } \\
\text { Method }\end{array}$ & $\begin{array}{l}\text { Help with students' } \\
\text { knowledge in } \\
\text { vocabulary increase } \\
\text { in all ways (prefix, } \\
\text { word root, suffix) }\end{array}$ & $\begin{array}{l}12 \\
\text { (t1s1, t1s7, t1s5, t1s7: } \\
\text { increase voc by outside } \\
\text { readers); } \\
\text { (t1s1, t1s6, t1s7: teach more } \\
\text { words in addition to the voc } \\
\text { in the articles); (t1s7: } \\
\text { guessing words from the } \\
\text { context); (t1s7: memorize } \\
\text { words by synonyms); (t1s5, } \\
\text { t1s7: memorize voc from the } \\
\text { context); (t1s6: listen more, } \\
\text { read more and speak more) }\end{array}$ & $\begin{array}{l}15 \\
(\mathrm{t} 2 \mathrm{~s} 3, \mathrm{t} 2 \mathrm{~s} 4, \mathrm{t} 2 \mathrm{~s} 5, \\
\text { t2s6: word roots; } \\
\text { t2s1, t2s2, t2s3, } \\
\text { t2s5, t2s6: listen } \\
\text { more, read more } \\
\text { and speak more; } \\
\text { (t2s1, t2s } 2, \mathrm{t} 2 \mathrm{~s} 3, \\
\text { t2s } 4, \mathrm{t} 2 \mathrm{~s} 5, \mathrm{t} 2 \mathrm{~s} 6 \\
\text { increased) }\end{array}$ & $\begin{array}{l}12 \\
(\mathrm{t} 3 \mathrm{~s} 1, \mathrm{t} 3 \mathrm{~s} 2, \mathrm{t} 3 \mathrm{~s} 3, \mathrm{t} 3 \mathrm{~s} 4, \mathrm{t} 3 \mathrm{~s} 5, \\
\mathrm{t} 3 \mathrm{~s} 1: \text { word studies on puns); } \\
\text { (t3s1, t3s3: open mouth to } \\
\text { read or to speak); (t3s } 3 \text { : listen } \\
\text { more, read more and speak } \\
\text { more) } \\
(\mathrm{t} 3 \mathrm{~s} 1, \mathrm{t} 3 \mathrm{~s} 5, \mathrm{t} 3 \mathrm{~s} 6 \text { increased) }\end{array}$ & 39 \\
\hline $\begin{array}{l}\text { GT Method } \\
\text { or CLT } \\
\text { Method }\end{array}$ & $\begin{array}{l}\text { Help with students' } \\
\text { grammatical } \\
\text { knowledge }\end{array}$ & $\begin{array}{l}5 \\
\text { t1s5, t1s6, t1s7 (improved) } \\
\text { T1s4,t1s5 }\end{array}$ & $\begin{array}{l}3 \\
\text { t2s } 3, \mathrm{t} 2 \mathrm{~s} 6 \\
\text { (improved) }\end{array}$ & $\begin{array}{l}9 \\
\text { t3s1, t3s } 2, \mathrm{t} 3 \mathrm{~s} 5, \mathrm{t} 3 \mathrm{~s} 6 \\
\text { (improve) } \\
\text { t3s1, t3s2, t3s } 3, \mathrm{t} 3 \mathrm{~s} 4, \mathrm{t} 3 \mathrm{~s} 5\end{array}$ & 17 \\
\hline $\begin{array}{l}\text { GT Method } \\
\text { or CLT } \\
\text { Method }\end{array}$ & $\begin{array}{l}\text { Enhance students' } \\
\text { knowledge with } \\
\text { reading } \\
\text { comprehension } \\
\text { (finding the theme, } \\
\text { main ideas, topic } \\
\text { sentences, etc.) }\end{array}$ & $\begin{array}{l}7 \\
\mathrm{t} 1 \mathrm{~s} 5, \mathrm{t} 1 \mathrm{~s} 7 \\
\text { (t1s2, t1s } 3, \mathrm{t} 1 \mathrm{~s} 5, \mathrm{t} 1 \mathrm{~s} 6, \mathrm{t} 1 \mathrm{~s} 7 \\
\text { enhanced) }\end{array}$ & $\begin{array}{l}8 \\
\mathrm{t} 2 \mathrm{~s} 2, \mathrm{t} 2 \mathrm{~s} 6 \\
(\mathrm{t} 2 \mathrm{~s} 1, \mathrm{t} 2 \mathrm{~s} 2, \mathrm{t} 2 \mathrm{~s} 3, \\
\mathrm{t} 2 \mathrm{~s} 4, \mathrm{t} 2 \mathrm{~s} 5, \mathrm{t} 2 \mathrm{~s} 6 \\
\text { enhanced) }\end{array}$ & $\begin{array}{l}5 \\
\mathrm{t} 3 \mathrm{~s} 4 \\
\text { (t3s1, t3s4, t3s } 5, \mathrm{t} 3 \mathrm{~s} 6 \\
\text { enhanced) }\end{array}$ & 20 \\
\hline $\begin{array}{l}\text { Counts for } \\
\text { GT or CLT } \\
\text { Methods }\end{array}$ & & 24 & 26 & 26 & 76 \\
\hline \multirow[t]{2}{*}{ CLT Method } & $\begin{array}{l}\text { Enhance their } \\
\text { listening via Film } \\
\text { watching }\end{array}$ & $\begin{array}{l}7 \\
\mathrm{t} 1 \mathrm{~s} 1, \mathrm{t} 1 \mathrm{~s} 2, \mathrm{t} 1 \mathrm{~s} 3, \mathrm{t} 1 \mathrm{~s} 4, \mathrm{t} 1 \mathrm{~s} 5, \\
\mathrm{t} 1 \mathrm{~s} 6, \mathrm{t} 1 \mathrm{~s} 7\end{array}$ & $\begin{array}{l}6 \\
\mathrm{t} 2 \mathrm{~s} 1, \mathrm{t} 2 \mathrm{~s} 2, \mathrm{t} 2 \mathrm{~s} 3, \\
\mathrm{t} 2 \mathrm{~s} 4, \mathrm{t} 2 \mathrm{~s} 5, \mathrm{t} 2 \mathrm{~s} 6\end{array}$ & $\begin{array}{l}6 \\
\text { t3s } 1, t 3 s 2, t 3 s 3, t 3 s 4, t 3 s 5, \\
\text { t3s6 }\end{array}$ & 19 \\
\hline & $\begin{array}{l}\text { Assign outside class } \\
\text { readers }\end{array}$ & $\begin{array}{l}4 \\
\mathrm{t} 1 \mathrm{~s} 1, \mathrm{t} 1 \mathrm{~s} 5, \mathrm{t} 1 \mathrm{~s} 6, \mathrm{t} 1 \mathrm{~s} 7\end{array}$ & $\begin{array}{l}5 \\
\text { t2s } 1, \mathrm{t} 2 \mathrm{~s} 2, \mathrm{t} 2 \mathrm{~s} 3, \\
\mathrm{t} 2 \mathrm{~s} 4, \mathrm{t} 2 \mathrm{~s} 6\end{array}$ & $\begin{array}{l}2 \\
\mathrm{t} 3 \mathrm{~s} 4, \mathrm{t} 3 \mathrm{~s} 5\end{array}$ & 11 \\
\hline \multirow[t]{2}{*}{ CLT Method } & $\begin{array}{l}\text { Welcome students to } \\
\text { ask questions via } \\
\text { e-mail }\end{array}$ & & & $\begin{array}{l}1 \\
\text { (t3s1: welcome to ask } \\
\text { question by e-mail to } \\
\text { teacher) }\end{array}$ & 1 \\
\hline & $\begin{array}{l}\text { Playing games (i.e. } \\
\text { jigsaw, by } \\
\text { individuals or in } \\
\text { groups }\end{array}$ & $\begin{array}{l}2 \\
\mathrm{t} 1 \mathrm{~s} 5, \mathrm{t} 1 \mathrm{~s} 6\end{array}$ & $\begin{array}{l}4 \\
\text { t2s } 3, t 2 s 4, t 2 s 5 \\
\text { t2s6 }\end{array}$ & $\begin{array}{l}3 \\
\mathrm{t} 3 \mathrm{~s} 3, \mathrm{t} 3 \mathrm{~s} 4, \mathrm{t} 3 \mathrm{~s} 5\end{array}$ & 9 \\
\hline $\begin{array}{l}\text { Counts for } \\
\text { CLT method }\end{array}$ & & 13 & 15 & 12 & 40 \\
\hline CL Method & $\begin{array}{l}\text { collaborative work } \\
\text { through group } \\
\text { discussion and } \\
\text { group presentation }\end{array}$ & $\begin{array}{l}8 \\
\mathrm{t} 1 \mathrm{~s} 1, \mathrm{t} 1 \mathrm{~s} 2, \mathrm{t} 1 \mathrm{~s} 3, \mathrm{t} 1 \mathrm{~s} 4, \mathrm{t} 1 \mathrm{~s} 5 \\
\mathrm{t} 1 \mathrm{~s} 6, \mathrm{t} 1 \mathrm{~s} 7 \\
(\mathrm{t} 1 \mathrm{~s} 6)\end{array}$ & $\begin{array}{l}6 \\
\mathrm{t} 2 \mathrm{~s} 1, \mathrm{t} 2 \mathrm{~s} 2, \mathrm{t} 2 \mathrm{~s} 3, \\
\mathrm{t} 2 \mathrm{~s} 4, \mathrm{t} 2 \mathrm{~s} 5, \mathrm{t} 2 \mathrm{~s} 6\end{array}$ & $\begin{array}{l}6 \\
\text { t3s } 1, t 3 s 2, t 3 s 3, t 3 s 4, t 3 s 5, \\
\text { t3s6 }\end{array}$ & 20 \\
\hline $\begin{array}{l}\text { Total counts } \\
\text { for all } \\
\text { methods }\end{array}$ & & 45 & 47 & 44 & 136 \\
\hline
\end{tabular}

Table 4 displays the allotted time the three teachers used for the combined method of GT, CLT and CL methods. Teacher Chang adopted $60 \%$ of the time on the GT, $10 \%$ on CLT and $30 \%$ on CL; Teacher Her spent $50 \%$ of the time on CLT and $50 \%$ on CL and Teacher Chen used $30 \%$ of the time on the GT, $30 \%$ on CLT and $40 \%$ on CL. Therefore, the results indicated that a successful teaching could not be attributed to a single superior method; the cooperative learning techniques of CLT and CL methods combined with the GT traditional teaching instruction worked effectively for the EFL university students. 
TABLE 4:

THE PERCENTAGE OF CLASS TIME ON TEACHING METHODS FROM TEACHER INTERVIEW AND CLASSROOM OBSERVATION

\begin{tabular}{|l|l|l|l|l|}
\hline & & Teacher Chang & Teacher Her & Teacher Chen \\
\hline The GT method & Q2:Teaching vocabulary & $\checkmark(20 \%)$ & & $\checkmark(10 \%)$ \\
\hline & Q3: Teaching grammar & $\checkmark(30 \%)$ & & $\checkmark(10 \%)$ \\
\hline & Q4: Essay structure & $\checkmark(10 \%)$ & & $\checkmark(10 \%)$ \\
\hline & Q2:Teaching vocabulary & & $\checkmark(20 \%)$ & \\
\hline & Q3: Teaching grammar & & $\checkmark(10 \%)$ & \\
\hline & Q4: Essay structure & & $\checkmark(20 \%)$ & $\checkmark(30 \%)$ \\
\hline CL & $\begin{array}{l}\text { Q6: Interaction between } \\
\text { teacher and students } \\
\text { (feedback in class or on } \\
\text { homework) }\end{array}$ & $\checkmark(10 \%)$ & & \\
\hline & Q6: Group discussion & Mostly prepared and done outside the class & \\
\hline & Group presentation & $\checkmark(10 \%)$ & $\checkmark(20 \%)$ & $\checkmark(20 \%)$ \\
\hline & $\begin{array}{l}\text { Q6: Interaction among } \\
\text { students }\end{array}$ & $\checkmark(10 \%)$ & $\checkmark(10 \%)$ & $\checkmark(10 \%)$ \\
\hline
\end{tabular}

\section{Students'Learning Achievement Based on Their Performance in the MEPT Post-test}

As cited in Chien, 2014, the paired t-tests found that students of all three teachers had made statistically significant improvement in overall performance over the four months of work in the second semester. Specifically, students taught by Teacher Chang showed significant improvement in reading; students taught by Teacher Her showed significant improvement in listening, grammar, and vocabulary; students taught by Teacher Chen showed significant improvement in listening and vocabulary. These results are comforting, considering each class involved in this study met only for two hours, once per week.

\section{CONCLUSION}

Although plenty of studies assert the effectiveness of specific teaching methods and practices, there is a lack of research examining the effectiveness from EFL learners' perceptions of their own learning experiences of the teaching methods in the existing theories on second/foreign language acquisition, especially within the EFL environments. The students' perceptions provide teachers rich information for understanding their students' cognition and classroom processes (Knight \& Waxman, 1991). The students' perceptions also enable researchers and teachers to understand students' thought processes (Tuan, Chang, Wang, \& Treagust, 2000). Learning tens to take place when students feel like entrusting themselves to their teacher's teaching, and are willing to try and to participate actively in learning activities which are new and challenging to them.

In the present study three model teachers were consistently highly judged by the students' evaluation reports for years and the improvements of students' English are significant, the proficiency being substantiated by the MEPT tests. The adopted teaching methods with practices are analyzed, compared and identified based on their syllabi, questionnaire surveys, student interviews with sampled students and teachers; and classroom observations. The analysis results show that the teaching methods make use of cooperative learning techniques in CLT and CL methods, even though two of the teachers in this study still adopted the GT traditional teaching method, but it was mainly students' doing the Chinese and English translation rather than teachers' using a traditional lecture-style. All of the three teachers successfully created an atmosphere unlike the traditional teaching environment, in which students need to take more responsibility for their learning. To sum up, all of the teaching methods discussed above contributed to creating an environment that had a certain novelty to it which inspired students and kept up the levels of interest and participation.

\section{ACKNOWLEDGEMENT}

The author wishes to thank Dr. Laura Wang of the Language Center, Chung Yuan Christian University, for her full support of the study and Dr. Margaretha Hsu, Shippensburg University, USA for the statistical analysis.

\section{FUNDING ACKNOWLEDGEMENT}

This work was supported by the National Science Council, Taiwan, ROC [grant number NSC 99-2410-H-033-052].

\section{REFERENCES}

[1] Brody C. M. \& Davidson, N. (1998). Professional development for cooperative learning: Issues and approaches. Albany: State University of New York Press.

[2] Brown, H. D. (2007). Teaching by principles: An interactive approach to language pedagogy ( $3^{\text {rd }}$ ed.). White Plains, NY: Pearson Education.

[3] Chen, L. H. (2001). The effectiveness of grouping in an EFL cooperative learning classroom. Taipei, Taiwan: Tamkang University Press. 
[4] Chien, C. N. (2014). Common attributes of outstanding college EFL teachers' teaching. Journal of Language Teaching and Research, 5, 437-445.

[5] Chien, C. N., Kao, L. H. \& Ching, H. L. (2011). Differences in English learning motivation among University EFL learners in Taiwan, Chang Jung Journal, 15(2), 77-98.

[6] Chomsky, N. (1957). Syntactic structures. The Hague: Mouton.

[7] Dornyei, Z. (1997). Psychological processes in cooperative language learning: Group dynamics and motivation, The Modern Language Journal, 81(4), 482-493.

[8] Howatt, A. P. R., \& Widdowson, H. G. (2004). A history of English language teaching. (2nd ed.) Oxford: Oxford University Press.

[9] Johnson, D. W., Johnson, R. T., \& Smith, K. A. (1995). Cooperative learning and individual student achievement in secondary schools. In J. E. Pedersen \& A. D. Digby (Eds.), Secondary schools and cooperative learning: Theories, models, and strategies (pp. 3-54). New York: Garland.

[10] Knight, S. L., \& Waxman, H. C. (1991). Analyzing effective teaching of Hispanic students' problem-solving strategies in Spanish. NABE Annual Conference Journal, 1988-1989. Washington, DC: National Association for Bilingual Education.

[11] Khandelwal, K.A. (2009). Effective teaching behaviors in the college classroom: a critical incident technique from students' perspective. International Journal of Teaching and Learning in Higher Education, 21(3), 299-309.

[12] Lo, Z. H. (2005). The serious academic gap between high- and low-achieving English learners on the Joint College of Entrance Examination: Educators worry. Retrieved July 12, 2005, from http://www.wfdn.com.tw/9403/050306/01-08/030603-1.htm.

[13] Magno, C., \& Sembrano, J. (2007). The role of teacher efficacy and characteristics on teaching effectiveness, performance, and use of learner-centered practices. The Asia-Pacific Education Researcher, 16(1), 73-90.

[14] McComs, B. L., \& Whisler, J. S. (1997). The learner-centered classroom and school: Strategies for increasing student motivation and achievement. San Francisco: Jossey-Bass.

[15] Millis, B. J. \& Rhem, J. (2010). Cooperative learning in higher education: Across the disciplines. Stylus Publishing, LLC.

[16] Nunan, D. (1988). The Learner-centered Curriculum. Cambridge: Cambridge University Press.

[17] Richards, J. C. \& Theodore, R. S. (2001). Approaches and methods in language teaching. (2nd ed.) Cambridge: Cambridge University Press.

[18] Richards, J. C. (2006). Communicative language teaching today. Cambridge: Cambridge University Press.

[19] San, H. Y. (2005). To raise the score of zero, eliminate multiple choice questions and institute an essay answer. Retrieved July 10, 2005, from http://www.libertytimes.com.tw/2005/new/feb/26/today-life1.htm.

[20] Sapargul, D., \& Sartor, V. (2010). The trans-cultural comparative literature method: Using grammar-translation techniques effectively. English Teaching Forum, 48(3), 26-33.

[21] Savignon, S. J. (1983). Communicative competence: Theory and classroom practice. Reading, Mass.: Addison Wesley.

[22] Strong, M., Gargani, J., \& Hacifazlioglu, O. (2011). Do we know a successful teacher when we see one? Experiments in the identification of effective teachers. Journal of Teacher Education, 62(4), 367-382.

[23] Tuan, H. L., Chang, H. P., Wang, K. H. \& Treagust, D. F. (2000). The development of an instrument for assessing students' perceptions of teachers' knowledge. International Journal of Science Education, 22(4), 385-398.

[24] Wang, Tzu-Pu. (2007). The comparison of the difficulties between cooperative learning and traditional teaching methods in college English teachers. The Journal of Human Resource and Adult Learning, 3(2), 23 - 30.

[25] Wei, K. L. (1996). Perspectives of Taiwan college EFL learners about cooperative learning. Educational Research \& Information, 4(6), $13-26$.

[26] Wilkins, D. A. (1972). The linguistics and situational content of the common core in a unit/credit system. MS. Strasbourg: Council of Europe.

[27] Wilkins, D. A. (1976). Notional syllabuses. Oxford: Oxford University Press.

Ching-ning Chien holds M.A. degrees in Special Education from Tennessee Technological University and in English Education from Ohio State University, as well as a Ph.D. degree in Education from the University of Newcastle upon Tyne, England. She is currently an associate professor in Applied Linguistics at Chung Yuan Christian University where she teaches listening, speaking and reading to freshman students. Her research interests include foreign language listening comprehension, foreign language learning and teaching, bilingualism, phonological awareness and second language acquisition. 